\title{
Continuous rigid frame bridge side span and mid-span ratio of optimization and analysis
}

\author{
Xiuling He \\ Yunnan Jiaotong College, Kunming 650500, China; \\ 762104710@qq.com,
}

Keywords: Side span and mid-span ratio, MIDAS CIVIL, continuous rigid frame bridge.

\begin{abstract}
The bridge prestressed concrete continuous rigid frame bridge is a kind of good integrity, reasonable force, construction technology is mature, moderate cost, spanning ability and driving comfort, etc.And in the actual project got a lot of applications while further development prospects are very bright. After a long design practice, continuous rigid frame bridge design parameters have been gradual development and optimization. With MIDAS CIVIL modeling and analysis approach to each side span and mid-span ratio as an indicator, through the analysis of the results obtained will help improve the performance of the main beam span parameter combinations.
\end{abstract}

\section{Introduction}

Prestressed continuous rigid frame bridge originated in the 1950s in the Federal Republic of Germany. Using upper main beams and piers rigid connection of Warren Williams (worms) bridge, basically solved the big span prestressed concrete bridge problem in terms of construction technology, and created a new T-type rigid frame bridge. This marks the beginning of prestressed concrete continuous rigid frame bridge of large span, and then began a rapid development. Thereafter, the rigid frame of the main bridge in Germany this Astoria (bendorf) bridge, bingo name Japan Bridge across have reached more than 200m. However, due to limitations of the technology and experience at the time, the structure of the main span across the set of Shear hinge manner, in closed area bear only axial force and shear, temperature and other factors and therefore produce a deformation of the zigzag road in the hinge point Ride created a very negative impact, while the design of the steel structure system brought about by concrete shrinkage and creep factors such as lack of knowledge. With the span is increasing, these negative factors for the conservation and road bridges have had increasingly adverse effects.

\section{Project Overview}

Select the engineering background of a highway in Yunnan Province a prestressed concrete continuous rigid frame bridge, bridge main span $103 \mathrm{~m}+190 \mathrm{~m}+103 \mathrm{~m}$ form, constituted by two T, the total length of the main bridge bridge $396 \mathrm{~m}$. Design of the upper part of the main beam of Single Cell Box situ prestressed reinforced concrete box girder, box girder top width of $12 \mathrm{~m}$, bottom width of $6.5 \mathrm{~m}$. Pier at the height of $12 \mathrm{~m}$ box girder, box girder span at high $3.8 \mathrm{~m}$, web thickness was $0.8 \mathrm{~m}, 0.6 \mathrm{~m}, 0.5 \mathrm{~m}$, plate thickness by 1.6 times from the mid-span of the parabola change caused by $0.32 \mathrm{~m}$ at the pier $1.4 \mathrm{~m}$.Box girder 0 \# Number block length $15 \mathrm{~m}$, pier Dingli touch pouring. Rigid boom section with Traveler Symmetrical pouring cast long segment in $3 \sim 5 \mathrm{~m}$, to cross from the roots in $5 \times 3 \mathrm{~m}, 5 \times 3.5 \mathrm{~m}, 6 \times 4 \mathrm{~m}, 6 \times 5 \mathrm{~m}$, a total of 22 beams, the largest segment of Main Beam of Concrete weight 250t. There are two full-bridge Cross Close segment and a mid-span folded segment length is $2 \mathrm{~m}$, two side cross-section of each of the long cast $7 \mathrm{~m}$, using the guide beam cast construction. Box beam using longitudinal, vertical two-way prestressed structure, vertical prestressing steel anchor using coarse thread finishing system, using a large-tonnage group longitudinal anchor anchorage system. Piers reinforced concrete double - thin wall hollow pier. 


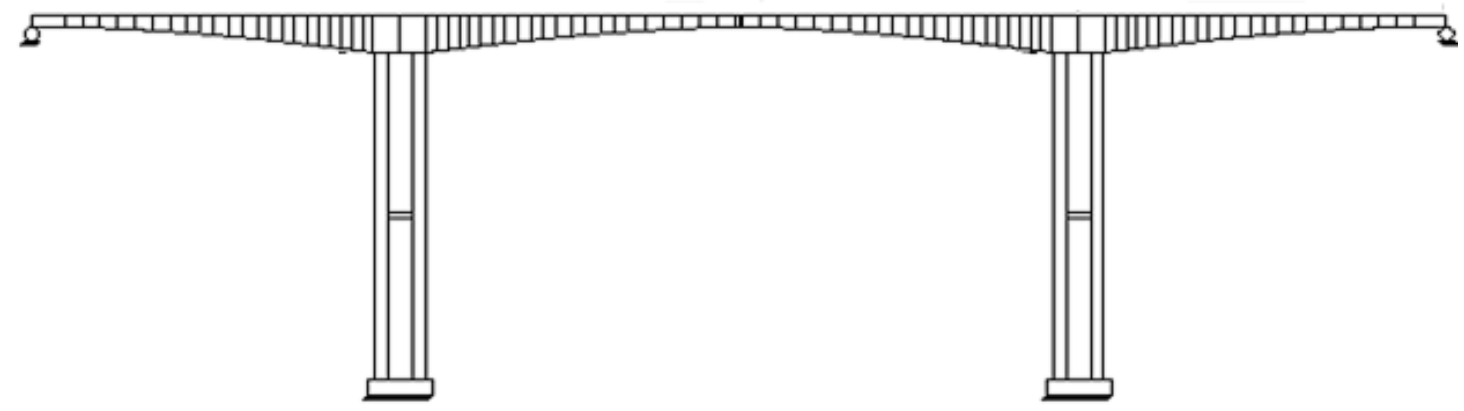

Fig. 1 Facade layout

\section{Calculated parameters design standards and material properties}

1 The design reference period: 100 years;

2 Highway rating: secondary road;

3 The vehicle load standards: road -I level; crowd load (2.5KN / m);

4 Calculate the driving speed: $60 \mathrm{~km} / \mathrm{h}$;

5 Peak ground acceleration: $0.2 \mathrm{~g}$; basic seismic intensity: VIII degrees.

\section{Model}

In this paper, the background of the continuous rigid frame bridge project as the basis, establish the appropriate finite element model. When the bridge modeling engineering background included a longitudinal prestressing effects. Meanwhile, due to the arrangement of prestressed steel beam as a continuous rigid frame bridge design, a very important factor in optimizing the design in general as a separate factor independent analysis and optimization parameters selected herein as a continuous rigid frame bridge in the side span ratio parameter and related parameters main beam section. Therefore, in order to define these parameters herein chosen continuous rigid frame bridge by impact force characteristics, by changing the parameters in the model established in prestressed steel beam length or position only made minor adjustments.

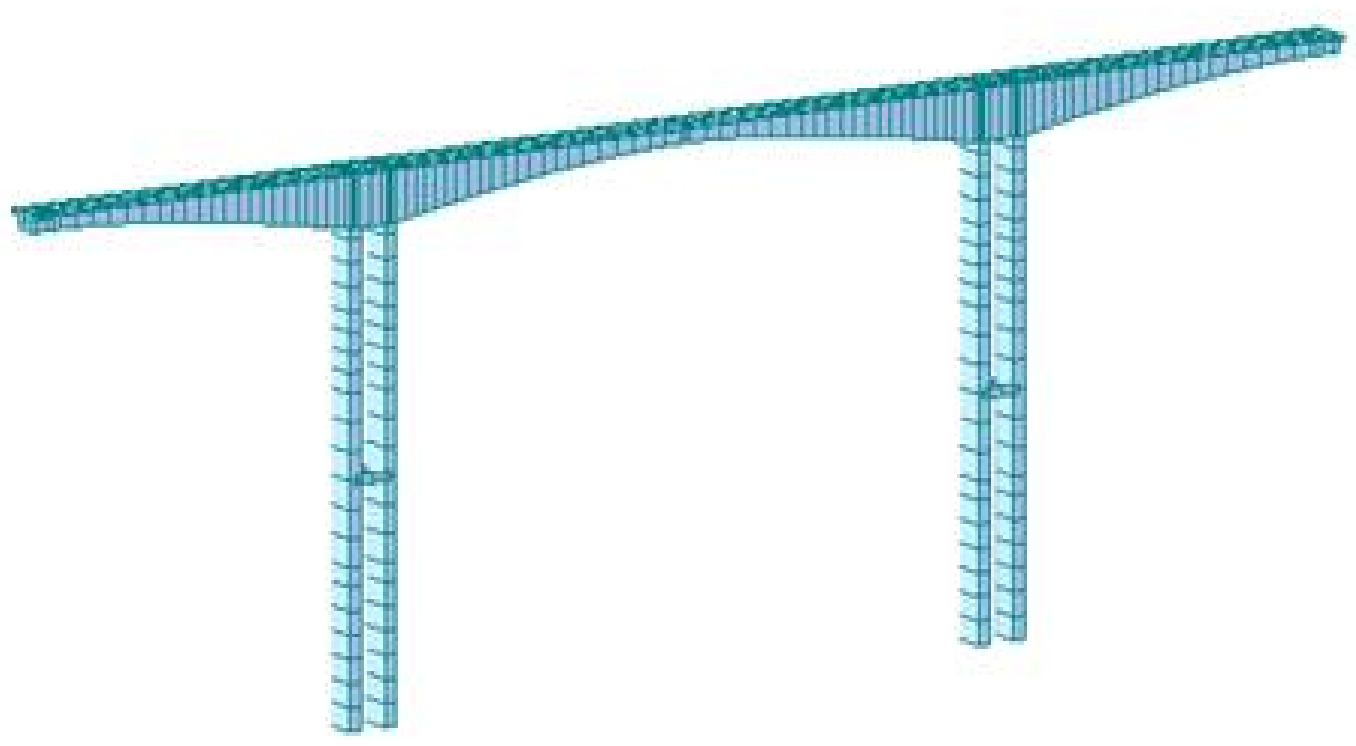

Fig. 2 Full bridge finite element model

Analysis of the sides in order to effectively cross Ratio parameters individually optimized, need to first determine the range commonly used in general lower than the span. According to some continuous rigid frame bridge across the edge at home and abroad than the data were aggregated results shown in Table 1. 
Table 1 Partially prestressed concrete continuous rigid frame bridge in the side span ratio

\begin{tabular}{|c|c|c|c|}
\hline No. & Bridge Name & $\begin{array}{c}\text { The main bridge span } \\
(\mathrm{m})\end{array}$ & $\begin{array}{c}\text { Side span and mid-span } \\
\text { ratio }\end{array}$ \\
\hline 1 & Raft sundet Bridge & $86+202+298+125$ & $0.678 / 0.419$ \\
\hline 2 & Comfederation Bridge & $165+3 * 250+165$ & 0.660 \\
\hline 3 & Gate Way Bridge & $145+260+145$ & 0.558 \\
\hline 4 & Houston Bridge & $114+228.6+114$ & 0.499 \\
\hline 5 & Hamana Bridge & $55+140+240+140+55$ & 0.538 \\
\hline 6 & Mooney Bridge & $130+220+130$ & 0.590 \\
\hline
\end{tabular}

By Table 1, it can be seen, continuous rigid frame bridge span ratio ranging sides relatively large, at 0.5 to 0.7 than the inner side of the span ranging, practical engineering examples have appeared. For larger span continuous rigid frame bridge, while the mid-span than most distributed in the 0.52 to 0.60 range. Meanwhile, as described in the relevant literature, while across most of the mid-span of span ratio ranged from 0.55 to 0.58 .

\section{Summary}

After comparing the calculation results of the analysis, we can see that: With the increase in side span ratio, under the most unfavorable load combinations across the moment and deflection decreases, at the fulcrum moment increases. Control other continuous rigid frame bridge parameters remain unchanged, while the value of taking sides span than 0.557 after optimization, to establish a new finite element model calculations. Obtained using the optimized parameters than the rear side of the span, the bridge under the most unfavorable load combination of maximum span moment is $229476 \mathrm{KNm}$, pier at the maximum bending moment is $-2033486 \mathrm{KNm}$, midspan deflection of $70.12 \mathrm{~mm}$. Optimization results show that cross-ratio calculation results with variation of sides, but also shows the actual project, while the mid-span than the selection of parameters is very reasonable.

\section{Acknowledgements}

This work was financially supported by the National Science Foundation of China (51068012) and the Yunnan Province Communications DepartmentScience and Technology Program (2013(c) 07).

\section{References}

[1] Liu Xiao Yao, Xu Yue Highway Bridge Design Manual Bridges [M] Beijing: China Communications Press, 2011.

References: [2] Shao Xudong bridge engineering [M] Beijing: China Communications Press, 2004.

[3] Zhou Junsheng, Lou Zhuang hung situation and development trend of continuous rigid frame bridge large span prestressed concrete [J] Chinese Journal of Highway, 2000.1: $34 \sim 40$.

[4] Ma Baolin, Lizi Qing long span continuous rigid frame bridge [M] Beijing: China Communications Press, 2004.

[5] Chang Xing Branch continuous rigid frame bridge unreasonable sides span ratio adjustment [J] highway, 2009.10: 26 to 29. 